\title{
Satura, saturæ: itinerários do misto \\ (preceptivas do poema herói-cômico no mundo luso-colonial)
}

Satura, saturæ: mixed itineraries

(perceptive of hero-comic poem in Portuguese-colonial world)

\section{Joaci Pereira Furtado}

Instituto de Arte e Comunicação Social da Universidade Federal Fluminense - UFF - Niterói - Rio de Janeiro - Brasil

\begin{abstract}
Resumo: Percurso da tradição do gênero satírico, desde seu surgimento na Grécia antiga até sua prática no universo letrado do século XVIII luso-colonial, objetivando indicar caminhos possíveis para a reconstituição das preceptivas que orientaram especialmente o poema herói-cômico, subgênero satírico com expressiva produção em Portugal e na América portuguesa.
\end{abstract}

Palavras-chave: Retórica. Sátira. Arcadismo.

Abstract: Course of the satirical genre tradition, since its emergence in ancient Greece to its practice in the literate world of Portugal in the eighteenth century, aiming to indicate possible ways to replenish the precepts that guided especially the hero-comic poem, satirical subgenre with significant production in Portugal and Portuguese America.

Keywords: Rhetoric. Satire. Arcadian. 


\section{Satura, saturæ: itinerários do misto} (preceptivas do poema herói-cômico no mundo luso-colonial) ${ }^{1}$

Messo homo, messo capra, tuto bestia. Giovanni Battista Guarini

Em 1830, três anos após publicar o "poema heroi-comico-satyrico" Os burros, ou o reinado da sandice, José Agostinho de Macedo, tendo os jesuítas como modelo, elogiava, numa espécie de monografia, a antiga produção poética lusitana, que Ihe parecia também condizente com o esmero com que os portugueses serviram a el-rei:

Com estes Legisladores Jesuitas [da poesia] quanto floreceo, e se dilatou este Imperio, tenuissimo, he verdade, mas que tem padecido, como os outros Imperios, suas alternativas de elevação, e grandeza, e de abatimento, e ruina - Fuit Illion, et ingens Gloria Teucrorum - em o nosso Portugal! Mas agora he razo campo onde foi Troia. Se mal se sabe escrever, que versos hão de apparecer? Eu não desejo ver os Portuguezes com versos, desejo-os ver convertidos para os caminhos da razão, e da justiça; e se não podem ser bons Poetas como antigamente erão, sejão bons vassallos como antigamente forão. Deitou-lhes a perder a Poesia o seiscentismo; deitou-lhes a perder a Politica o oitocentismo; não podem ser Luizes de Camões, pois não queirão ser Jacques Jooens; alguns estouvados querem ser Poetas, e todos os estouvados querem ser Licurgos, e Francklins; daqui estou vendo feita de véla a Charrua, que leva bastantes: já que tanto quizerão a Liberdade dos Cidadãos, justo he que vão ver o Captiveiro dos Negros. (MACEDO, p. 24)

O texto de Macedo - ao mesmo tempo arrebatada defesa dos jesuítas e veemente ataque ao liberalismo - é curioso por se situar no ocaso do absolutismo luso e de preceptivas retórico-poéticas que, cerca de cem anos antes, surgiram em meio à demolição das práticas políticas, pedagógicas e discursivas promovidas pela Companhia de Jesus e sob o estímulo da governação pombalina, posteriormente associada ao lluminismo ou às suas variantes. Esse escrito de Macedo, porém, talvez seja

\footnotetext{
${ }^{1}$ Versão reduzida e atualizada de capítulo da tese de doutorado A caligrafia dos afetos: o poema herói-cômico e a sociedade luso-americana, defendida em 2001 junto ao Programa de Pósgraduação em História Social da Universidade de São Paulo, sob os auspícios da Fundação de Amparo à Pesquisa do Estado de São Paulo (FAPESP).
}

um dos últimos espasmos de persistência de um mundo agora reduzido a ruínas em que produção poética, poder e fé - hoje tão estanques e capazes de provocar estranhamento quando tratados como se se equivalessem ou se complementassem, tal como faz o autor - não conheciam fronteiras. Mais precisamente, a defesa nem tanto de um suposto parâmetro jesuítico de poesia mas de determinada forma pregressa do fazer poético é, ao mesmo tempo, a reposição de certa prática discursiva tributária de uma sociedade fundada na hierarquia de privilégios, organizada por um Estado monárquico conduzido pelo poder absoluto do soberano, estratificada em classes conforme a propriedade de terras e favores distribuídos por esse mesmo Estado e permeada por valores e conceitos caros ao - ou afinados com o despotismo ilustrado também institucionalmente entranhado nas estruturas estatais. A poesia reivindicada por Macedo não tem sentido fora de um mundo que não seja assim, pois ela é um modo de articulação discursiva não psicológica da autopercepção daquela sociedade a partir da aplicação de tópicas, disposições, ornamentos, verossímeis e decoros retóricos segundo critérios como a repetição, a autoridade de modelos, a conservação do status quo, o domínio e a obediência de prescrições tanto por parte de quem escreve quanto de quem lê - ou, como lembra João Adolfo Hansen, a propósito da sátira seiscentista, "nela se recicla uma cultura paradigmática, no dizer de Lotman, em que tudo está de alguma forma já dito e em que a inovação só é pensável como rearticulação de fórmulas da tradição" (HANSEN, 1989, p. 40). Bastou que aquele mundo desaparecesse - ou ao menos sofresse transformações irreversíveis - para que não houvesse mais lugar para essa forma de poesia. A reação contrarrevolucionária, portanto, não é suficiente para explicar a vociferação do poeta contra o liberalismo e justificar seu inventário de inúmeras contribuições dos jesuítas aos diversos campos das ciências e das letras. A apologia da extinta Companhia de Jesus e a condenação do legado da Revolução Francesa eram, agora, a própria condição de existência da arte poética que, 
apreendida a partir de modelos da Antiguidade clássica - sempre reapropriados em todo o Ocidente, ao longo do tempo - , vigorara em Portugal na segunda metade do século XVIII. O esforço de conservar semelhante paradigma, como ficou indicado acima, seria irremediavelmente baldado naquele alvorecer do romantismo e da sociedade liberal-burguesa no reino luso.

Daí a importância de se recuperar a retórica, quando se inventa essa poesia como documento histórico. Complexo sistema de codificação da fala e da escrita que remonta à obra de Aristóteles acrescida e nuançada ao longo dos séculos por uma infinidade de preceptistas que, no entanto, conservaram os escritos do filósofo grego como epicentro -, desde Anaxímenes de Lâmpsaco a retórica previa três gêneros de discurso, por sua vez consoantes aos três gêneros de público demarcados pelos preceitos aristotélicos: deliberativo (que aconselha ou dissuade), judiciário (que acusa ou defende) e o epidítico — também chamado "demonstrativo" (que louva ou censura). A cada gênero corresponde um tempo adequado ao objeto de que se trata: o aconselhar ou o dissuadir são próprios do que há de ser, pertencendo o futuro, portanto, ao deliberativo; a acusação ou a defesa sempre se referem ao fato consumado, cabendo ao judiciário o tempo pretérito; e ao epidítico associa-se principalmente o presente, já que é em razão dos eventos contemporâneos que os oradores condenam ou louvam - o que não exclui a argumentação buscada ao passado ou a evocação das possibilidades que se abrem à conjuntura coeva. Por outro lado, como lembra Aristóteles, assim como o que é impossível não pode ser feito no presente ou no passado, e o que é irreal ou irrealizável é estranho ao pretérito ou ao porvir, é necessário não só qualificar algo como bom ou mal, belo ou feio, justo ou injusto, mas também verificar se a qualidade desse algo é grande ou pequena, maior ou menor, mais ou menos, universal ou individual etc. Contudo, na própria Retórica, a teoria aristotélica sofreu nuanças a ponto de se poder falar em passagem da "retórica antiga" para a "retórica recente" nessa obra do filósofo grego, cujo livro segundo introduz as "paixões" (páthe) "como argumento determinante da técnica retórica" e o ethos ("caráter") do orador como novo elemento discursivo (PLEBE, p. 41-2):

Ora, uma vez que a Arte Retórica tem por objetivo um juízo - com efeito, julgam-se os conselhos, e a decisão dos tribunais é igualmente um juízo -, é absolutamente necessário não ter só em vista os meios de tornar o discurso demonstrativo e persuasivo; requer-se ainda que o orador mostre possuir certas disposições e as inspire ao juiz. Para inspirar confiança, importa sobremaneira, principalmente nas assembleias deliberantes, e também nos processos, que aquêle que fala mostre-se sob certo aspecto, faça crer que se encontra em determinadas disposições a respeito dos ouvintes, e, além disso, encontre êstes nas mesmas disposições a respeito. (ARISTÓTELES, 1969, p. 115)

Em seguida a Aristóteles, gerando grande polêmica que retomou a disputa entre retórica e filosofia, outros pensadores se ocuparam das preceptivas discursivas, como os estóicos Zenão, Cleanto, Crisipo e Diógenes de Babilônia — de cujos preceitos se tem apenas notícias e fragmentos. A doutrina de Hermágoras de Temno (século II a. C.) também introduziu mudanças, mas aqui interessa a codificação latina - que, ao fim e ao cabo, sempre tomando Aristóteles como principal referência, balizou a teorização retórica no Ocidente (CURTIUS, p. 96106). Assim, a Rhetorica ad Herennium, obra anônima datável do princípio do século I a. C., retoma a classificação aristotélica dos três gêneros e, quanto às técnicas, prescreve cinco elementos fundamentais para a constituição dos discursos: invenção (euresis/inventio), disposição (taxis/dispositio/ordem), elocução (lexis/elocutio/ornamentação), memória (memoria) e pronunciação (pronuntiatio ou actio). A invenção consistia na operação de resgate de matérias, temas, argumentos, significações, referências e lugares-comuns (endoxa/loci/topoi) que o orador, poeta ou artesão lembrava (ou "achava") ao compor sua obra, tendo em vista os três gêneros da oratória. Ao mesmo tempo, e sempre conforme essa classificação, a construção retorizada dos discursos normatizava, como foi visto, as atitudes de quem os emitia (éthe/caracteres) e as reações de quem os recebia (pathos), pressupondo o valor pragmático de que, para se atingir o objetivo almejado, a fala deveria 
comover (movere) o ouvinte. A disposição, partindo do princípio de que a utilidade dos discursos é ensinar (docere/prodesse), visava ao ordenamento do todo e à consecução lógica das partes da obra de modo a obter clareza a fim de alcançar a "adesão do público a valores de opinião fundamentados pelo costume e por autoridades (auctoritas/consuetudo)" (HANSEN, 1997, p. 1). A elocução, tendo em vista que a obra deve deleitar (delectare), tratava de ornar (ornare, "armar") o discurso $\square$ sempre conforme o gênero - substituindo o sentido próprio pelo figurado por meio de tropos e figuras, evitando o excesso de ornamentos em detrimento da clareza e a ausência deles sob pena de incorrer em aridez e banalidade. A memoria (memorização do discurso) permitia ao orador fixar o texto na mente a partir de técnicas concebidas "em moldes espaciais", "retroactivas na disposição de obras literárias, por exemplo, na preferência pelo habitual esquema quinquepartido, como auxílio da memória (por causa dos cinco dedos da mão)" (LAUSBERG, p. 93). Quanto à pronuntiatio, por fim, trata-se da fase da elaboração que se ocupa da "pronunciação de um discurso" e dos "gestos concomitantes" (LAUSBERG, p. 93).

Não é uma casualidade, pois, que na poesia árcade - ou "neoclássica", como foi chamada posteriormente —, da qual a obra de Macedo é importante exemplo, os gêneros encomiástico e lírico tenham sido os mais praticados. Previsto no âmbito do gênero epidítico, o encômio remonta aos poemas de Píndaro (c. 522-438 a. C.) e aos discursos de Isócrates (c. 436-338 a. C.) - obras celebrativas de aristocratas ou dos feitos de atletas e heróis. Dos "elogios" e "panegíricos" gregos decorreram os modelos imitados em Roma sobretudo para louvar a ação dos imperadores e líderes militares, como se pode observar nas Odes de Horácio. Num Estado absolutista como era o reino luso do século XVIII, o louvor — direto ou indireto - não só do príncipe, mas igualmente de aristocratas e dos ocupantes da alta hierarquia civil, militar e religiosa, não representava apenas um modo de obterem-se mercês, mas o elogio do próprio absolutismo, da nação encarnada em seu soberano e da organização social sob o primado da nobreza. É o que se verifica percorrendo as obras de autores como Antônio Diniz da Cruz e Silva, Cláudio Manuel da Costa, Domingos Caldas Barbosa, Domingos dos Reis Quita, Francisco de Melo Franco, Francisco José Freire (ou Cândido Lusitano, como é mais conhecido), Francisco Manuel do Nascimento (ou Filinto Elísio), Inácio José de Alvarenga Peixoto, José Basílio da Gama Vilas Boas, Luís José Correia de Amaral França, Manuel Inácio da Silva Alvarenga, Manuel Maria Barbosa du Bocage, Nicolau Tolentino de Almeida, Pedro Joaquim Antônio Correia Garção e Tomás Antônio Gonzaga, entre outros.

Para a compreensão de obras como o "poema heroi-comico-satyrico" de Macedo, o estudo da retórica e particularmente da sátira pode se revelar bastante útil. Trata-se de uma forma de recuperar a materialidade do próprio discurso, evitando que categorias que the são externas ou estranhas produzam interpretações anacrônicas. Embora poemas como as Cartas chilenas sejam frequentemente lidos como "sátiras", o herói-cômico é um subgênero específico - ainda que se sirva largamente de recursos satíricos e muito se assemelhe à sátira, sobretudo por seu caráter misto. O misto, portanto, é o viés satírico mais marcante do poema herói-cômico - razão pela qual se passa a fazer aqui a memória do gênero. ${ }^{2}$

A sátira, apesar de praticada pela maioria dos poetas árcades, hoje permanece associada quase exclusivamente ao nome de Bocage - que, de fato, possui volumosa obra nesse gênero, ainda que a produção satírica de Nicolau Tolentino seja igualmente considerável. Então concebida como mescla de estilos, estruturalmente sem unidade para figurar a falta de unidade dos vícios, a sátira parodia prescrições dos demais gêneros ${ }^{3}$. Assim, prescrições

\footnotetext{
2 O termo "gênero", aqui, é utilizado como tradução de genos ou eidos, designando o que se poderia nomear com os termos "subgêneros", "tipos", "formas subordinadas" para diferenciá-los dos "grandes gêneros" (épica, lírica e drama). Contudo, como assegura Francisco Achcar, não há inconveniente em usar a palavra "para, conforme o contexto, designar as subdivisões de cada um deles". ACHCAR, p. 26 (nota).

${ }^{3}$ Comentando a máxima de Guarini citada por Ricardo de Turia (em 1616) - "Messo homo, messo capra, tuto bestia" definindo o poeta satírico, João Adolfo Hansen diz que, "Como o sátiro em que duas naturezas formam um terceiro, ela [a
} 
do lírico podem ser empregadas para vituperar as pretensões de uma mulher idosa que se presume atraente (como no soneto "A uma velha senhora", de Tolentino), imitação de fórmulas epistolares podem ser utilizadas para emprestar maior verossimilhança à história de um governo despótico que também parodia o épico (como nas Cartas chilenas), características da epopeia são aplicadas na depreciação de um falo hipertrofiado (como no poema "Ribeirada", de Bocage).

Precedendo a história do gênero satírico, há uma longa tradição cômica independente da codificação poética sobretudo latina, que cristalizou a sátira na forma contemplada aqui. De difícil reconstituição, esses precedentes passam pelos cantos fálicos dos rituais de fertilidade na Grécia antiga, referidos por Aristófanes nos Arcanos, até chegar às preceptivas da comédia - comentada na Poética, entre outros gêneros. Escrita quando desses rituais não restavam mais que sobrevivências tardias, a Poética já distinguia a natureza das matérias conforme o gênero de composição adotado. Determinada espécie de vício, porém, seria própria da comédia, pois esta é

[...] imitação de homens inferiores; não, todavia, quanto a toda a espécie de vícios, mas só quanto àquela parte do torpe que é o ridículo. O ridículo é apenas certo defeito, torpeza anódina e inocente; que bem 0 demonstra, por exemplo, a máscara cômica, que, sendo feia e disforme, não tem

sátira] não tem a unidade prescrita de outros gêneros; é mista, como mescla de alto e baixo, grave e livre, trágico e cômico, sério e burlesco. Basicamente inclusiva - 'dependente' ou 'polifônica' —, a sátira mistura tópicas variadas da invenção retórico-poética, amplificando formas e procedimentos da elocução. Ressalta, na sua voz fantástica, o hibridismo, na medida mesma em que é construída de citações eruditas, de sentenças irônicas, de descrições hiperbólicas, de agudezas e vilezas de estilo baixo e sórdido, de paródias dos gêneros elevados etc. Constitui-se, parte por parte, de sinédoques de gêneros oratórios e poéticos, e pode assumir qualquer forma. Partes e partes conflitam, segundo a referência de cada uma ao gênero que efetua $e$, ainda, segundo a inverossimilhança programática do misto, efeito da fantasia que fere o decoro do discurso segundo o verossímil poético (eikon) e o opinável retórico (endoxa). Em outros termos, a sátira encena códigos de recepção: cada parte que nela é misturada remete o destinatário a um todo ausente, convenção de gênero efetuada como subtexto interpretante da parte e da incompossibilidade das misturas. Como incongruência e inverosimilhança, as misturas fantásticas são categorizadas pelo destinatário em outro registro de adequação, o do delectare, prazer do vulgo, no caso, em chave do prodesse, utilidade da catarse e da aprendizagem". (HANSEN, 1989, p. 225-6) [expressão de] dor. (ARISTÓTELES, 1993, p. 34-5)

Contudo, o gênero poético misto vincado pelo caráter didático-moral, cujos modelos seriam largamente emulados no Ocidente, parece ter sido uma invenção romana. "Satura quidem forma nostra est”, diria Quintiliano, reivindicando o pioneirismo latino nessa forma de poesia que não encontrou precedente entre os gregos - ao menos no modo como ela se desenvolveu em Roma (BEVILACQUA, p. 3). É certo, conforme Michele Bevilacqua, que elementos burlescos podem ser localizados na Ilíada, que há um poema "épico-cômico" atribuído a Homero (o Margites), que os versos jâmbicos eram próprios do cômico, que Horácio atribui certa poesia mordaz à paródia filosófica do cínico Bion de Borístenes (Bioneis sermonibus), que há um misto de sério e faceto (spoudoghéloion) em Fênix de Cólofon, Cercidas de Megalópolis e sobretudo em Menipo. É correto também, por outro lado, que entre os latinos havia certo gênero de representação teatral jocosa de origem polêmica, sobre a qual restam dois testemunhos - Lívio e Valério Máximo - que, por sua vez, remetem a determinada forma de composição surgida sob o consulado de C. Sulpício Pético e C. Licínio Estolão (século IV a. C.). Diz Lívio que, diante dos males advindos de uma peste que se abateu sobre Roma naqueles anos (365 e 364 a. C.), intentou-se nova cerimônia religiosa para aplacar a ira dos deuses juntamente com a realização de encenações - fato novo para um povo dedicado à guerra e habituado aos espetáculos do circo, sublinha o relato. Nessas representações, prossegue Lívio, atores da Etrúria, dançando ritmadamente ao som de flauta, sem texto, sem gestos que imitassem algo, executavam movimentos dotados de certa graça à maneira etrusca ("ad tibicinis modos saltantes haud indecoros motus more Tusco dabant"). Em seguida, a juventude romana, agregando a prática de lançar ao mesmo tempo chistes recíprocos, passou a imitá-los em versos muito toscos e com movimentos que acompanhavam a voz - novidade que logo foi acolhida e repetida várias vezes. Os atores locais que se dedicaram à nova forma dramática foram 
chamados "histriões" ("nomen histrionibus inditum") — já que a palavra etrusca para "ator" era hister —, os quais agora representavam sátiras repletas de música com canto adequado ao som da flauta e com os respectivos movimentos (BEVILACQUA, p. 5-6). Para Bevilacqua, os jovens romanos encontraram nessas representações a forma adequada à zombaria, ao motejo licencioso, ao contraste verbal grosseiramente poético, à dança rústica - elementos já existentes no gênero fescenino, supostamente latino. O testemunho de Valério Máximo, posto que coincidente com o de Lívio em termos gerais, apresenta divergências de detalhes, principalmente em função de imprecisões ou referências vagas (BEVILACQUA, p. 7-10). Há inclusive a hipótese de que esses e outros relatos posteriores, imitando a Poética de Aristóteles e com isso se fundamentando na autoridade da tradição, inventaram uma origem romana para o teatro cômico latino da mesma forma que a comédia grega possuía a história de seu início. De qualquer maneira, à preexistente fescenina iocatio romana provavelmente se adicionaram elementos dramáticos etruscos, o que resultou no gênero teatral denominado satura (BEVILACQUA, p. 10).

A própria etimologia do termo, embora controversa, contribui para a compreensão do gênero, pois a palavra latina deriva, segundo a explicação mais aceita, de satura lanx - vaso repleto de primícias de diversa natureza apresentadas aos deuses em oferendas cerimoniais ${ }^{4}$. Assim, por analogia, as primeiras representações desse novo gênero cômico foram chamadas saturæ. O filólogo Vérrio Flaco (século I d. C.), por outro lado, afirma que satura é uma espécie de iguaria composta por diversos ingredientes ${ }^{5}$ e também uma lei que

\footnotetext{
4 Graça Videira Lopes segue outra hipótese para a etimologia da palavra: "Saturae, assim se denominavam os versos cantados na altura das vindimas na primitiva sociedade romana. Estes versos deviam o seu nome à mistura (satura) de vinho novo que era bebida num vaso, o satura lanx. De facto, na raiz de ambas as palavras (saturae, satura lanx) encontra-se, muito provavelmente, o grego satyro - os sátiros, figuras mitológicas sobejamente conhecidas da corte do deus Pã, tinham como principal tarefa, exactamente, as vindimas. Parece ser pois da união destes dois sentidos, os saturae romanos e o satyro grego que nasce, por alturas do séc. I a. C., a palavra sátira com o sentido que ainda hoje lhe atribuímos". LOPES, p. 36-7.

${ }^{5}$ Varrão, lembrado por Manuel Balasch, fala de uma espécie de salsicha que se recheava com variados ingredientes que
}

compreende diferentes matérias. Já para o gramático Diomedes (século IV d. C.), satura é um poema em que são tratados argumentos ridículos e obscenos, assim como um tipo de recheio constituído por vários elementos - além de a palavra remeter à referida oferenda cerimonial. Segundo Bevilacqua, citando Gilbert Highet, a remissão à satura lanx e ao componente culinário é o dado mais plausível e fidedigno para que se possa traçar a etimologia do termo que designa a composição em verso e prosa que em Roma era representada cenicamente acompanhada de música, com grande variedade de estilo e argumento, usando-se a linguagem corrente, com frequentes intromissões da persona do autor e predileção pelo humor, pela ironia, pela vivacidade das descrições, pela obscenidade e pelo tom de improviso, sempre visando a repreender a sociedade desnudando seus vícios e imprudências (BEVILACQUA, p. 11-2).

$\mathrm{Da}$ poesia satírica os registros coevos deixaram vestígios bem mais abundantes do que aqueles legados pela sátira dramática, além de restar a obra de seus principais autores: Horácio, Pérsio e Juvenal. Dos versos de Ênio, Pacúvio, Lucílio e Varrão, entretanto, perdeu-se grande parte, além de haver notícia deles em Quintiliano e Diomedes. Ainda assim, a natureza das sátiras de Ênio permanece ignorada, pois as referências contemporâneas falam em saturae (no plural) - o que remete muito mais à variedade da forma do que a um gênero específico (BEVILACQUA, p. 19). Dos versos satíricos de Pacúvio restou apenas notícia (CENTRANGOLO, p. 14).

Embora as fontes textuais não permitam estabelecer aproximações explícitas entre ambas, conforme lembra Bevilacqua, é certo que a sátira dramática e a poesia satírica ao menos coincidem em seus propósitos. Assim, somente a partir de Lucílio, no século II a. C., é possível verificar com segurança a existência da sátira romana. De fato, observa Bevilacqua, os escritos satíricos de Lucílio tratam de toda sorte de questões políticas, sociais e morais -

também se chamava satura. BALASCH in FLACO \& JUVENAL, p. 10. 
mas sobretudo da política. Logo num de seus primeiros livros, datável de 131 a. C. e posteriormente intitulado Deorum concilium pelos gramáticos, Lucílio ataca o princeps senatus Cornélio Lêntulo Lupo, servindo-se de uma paródia épica em que Jove preside um concílio de deuses segundo as regras das sessões do Senado romano para tomar sérias providências contra a corrupção dos costumes. O concílio decide-se pela morte do único responsável por esse mal: Lupo, cujo retrato é traçado com mordacidade. No livro sexto, em nítido alinhamento com o estoicismo, sempre em formas variadas (diálogos, cartas, textos expositivos), encontram-se repreensões aos vícios e crimes da aristocracia e, em fragmentos diversos de outros livros, a censura ao luxo e à prodigalidade dos ricos e a ridicularização das controvérsias religiosas e filosóficas (BEVILACQUA, p. 26-7).

Nas Saturae menippeae de Varrão, já no século I a. C., evidenciam-se, de acordo com Bevilacqua, características como a mistura de prosa e verso, a coloração cínica da matéria e o uso do kunikós tropos (maneira cínica de repreender os vícios rindo). Em Varrão, entretanto, não se objetiva a hilaritas de Menipo, mas a gravitas - que se traduz na sua severitas contra o luxo e a corrupção distinguindo-se da acrimonia luciliana apenas pelo anonimato de suas personagens. Assim, impera em sua obra a apologia do Estado, do culto aos deuses, da eficácia das leis, dos antigos costumes, da família, da lealdade aos amigos - tendo como público os cidadãos (o que, evidentemente, excluía o que a sociedade romana entendia como não cidadãos), buscando chamar-lhes a atenção para os males que os ameaçavam (BEVILACQUA, p. 31-3).

Em Horácio a função didático-moral do gênero parece acentuar-se - ou ao menos consolidar-se ${ }^{6}$ uma vez que nenhum outro autor latino, segundo assevera Bevilacqua, teria participado de modo tão intenso da diatribe cínico-estóica como Horácio, em

\footnotetext{
6 Para Graça Lopes, "Com Horácio as invectivas jâmbicas ganham o estatuto de género literário de pleno direito (que, como vimos, não tinham em Aristóteles), com uma função explicitamente social que é a de, pela crítica, moralizar os costumes". LOPES, p. 43.
}

cujas sátiras estão presentes temas como a perfeição da virtude do sábio, a raridade dos verdadeiros judiciosos - que podem desafiar até a fortuna - a nobreza como mérito e não como bem que se adquire com o nascimento, a superioridade da vida no campo em face da vida na cidade, a precedência da comida modesta sobre os lautos banquetes, a contenção do adultério, a limitação das necessidades humanas ao indispensável, a riqueza como um falso bem (BEVILACQUA, p. 48) ${ }^{7}$. Espécie de veículo de preceptivas morais, a sátira horaciana - conforme dizem Gian Franco Gianotti e Adriano Pennacini parece operar com modelos filosóficos diversos, dos quais foram retirados ensinamentos éticos que compõem um sistema coerente. Assim, da escola epicurista e de Lucrécio foi extraído o ideal da vida reservada e discreta, distante das perturbações e afeita aos pequenos prazeres naturais - mas, ao mesmo tempo, o poeta renuncia à rígida classificação dos prazeres e ao rigorismo moral característicos da escola de Epicuro. Da filosofia aristotélica deriva a noção da virtude como a justa medida entre vícios opostos: a metriotés do filósofo grego traduz-se, na obra de Horácio, como mediocritas, como modus, como senso de moderação, que, na verdade, significa recusa mesmo aos melhores excessos que porventura o amor ao bem possa propiciar. Mas não são apenas as escolas filosóficas que substanciam as sátiras de Horácio. Elas encontram matéria na antiga comédia grega, na poesia epigramática e sobretudo na tradição da diatribe cínico-estóica. Assim como Lucrécio e outros autores latinos que enfrentaram questões de cunho moralizante, Horácio se serve frequentemente do enorme reservatório de máximas estratificado nas prédicas dos filósofos "populares" da era helenística (diatribe), onde busca os lugarescomuns mais aprovados e procedimentos compositivos como a personificação dos conceitos de maior abstração, presença de um interlocutor fictício

\footnotetext{
7 "O riso moralizador é pois o pressuposto geral que define os poemas jâmbicos horacianos e que os distingue, enquanto sátira, ou seja, como forma literária, da simples maledicência circunstancial. É um pressuposto que marcará definitivamente toda a literatura satírica ocidental (pelo menos a de tradição clássica)." LOPES, p. 45-6.
} 
para avivar a cena e estrutura dialógica. Todavia, os motivos tradicionais, que haviam permitido aos filósofos cínicos contestar a sociedade dos potentados em nome dos valores do indivíduo, perdem sua carga corrosiva e se transformam numa longa série de preceitos morais. Contra os opulentos e os que buscam felicidade e riqueza, Horácio propõe como modelo de comportamento o ideal da autarkeia, da auto-suficiência do sábio - ponto comum entre diversas escolas filosóficas helenísticas. Recusando os prazeres supérfluos e evitando os excessos opostos dos vícios, o sábio horaciano melhora a si mesmo e controla as paixões. O modus torna-se assim o estado ideal - apesar das incertezas e recaídas - em que se alcança a tranquilidade do ânimo e se dominam as paixões. Estas, longe de serem negadas, são progressivamente atenuadas sob os golpes de uma contida ironia. Enfim, tal como a figura do príncipe, posta acima das facções sociais - sujeitos históricos das paixões políticas - e que se faz mediadora das divergências, o sábio horaciano encontra na mediocritas sua própria independência moral (GIANOTTI \& PENNACINI, v. 2, p. 129-30). Princípio que se constitui também como critério compositivo reverberado na própria organização do discurso poético por meio da mediania (medietas) da forma. O sermo horaciano, dirigido a um público restrito e de elite — os equites ("cavaleiros") —, decorre de uma pesquisa estilística homóloga à conduta ética preconizada pela persona satírica e encontra no tom mediano o modo adequado à sua veiculação: todas as vezes que a tonalidade dos versos parece elevar-se ou tender à solenidade, a intervenção do poeta procura o reequilíbrio através do discurso baixo, recorrendo a imagens jocosas, a observações benévolas, a expressões populares, ao emprego de vulgarismos e diminutivos, determinando a urbana elegância e a aparente espontaneidade programaticamente perseguidas pelo autor (GIANOTTI \& PENNACINI, v. 2, p. 130).

Posta a serviço do estoicismo - e tendo Lucílio e Horácio como modelos explícitos - a sátira de Aulo Pérsio Flaco (34-62 d. C.), também destinada a um público de elite, assume posturas ou trata de assuntos caros a essa corrente filosófica: o ataque à moda das declamações públicas e do gosto helenizante que impera nos ambientes onde se cultivava a poesia, a censura à religiosidade formal e hipócrita, a condenação da vida dissoluta e ociosa dos jovens rebentos da aristocracia do dinheiro, a crítica aos que ocupam cargos públicos sem se conhecerem a si mesmos, a repreensão dos avaros e de todos que não fazem bom uso dos próprios bens, a apologia da "verdadeira liberdade" segundo o estoicismo - isto é, aquela interior ao sábio, que aprendeu a se libertar dos vícios e que elege como único guia a própria consciência. Nas sátiras de Pérsio domina o ideal estoico de relação entre os homens e os deuses - que o poeta vê cotidianamente traído pelo comportamento das gentes, ocupadas com o baixo mercadejar dos bens materiais e de um equivocado bem-estar, movendo na persona satírica ora um sorriso moderadamente benévolo, ora o menoscabo, ora a ironia, ora a náusea (GIANOTTI \& PENNACINI, v. 2, p. 57-8). Seus versos entrelaçam a perfeição com a moral, a filosofia e a religião, concebendo homens elevados acima das vaidades e das desventuras - por isso ataca os covardes, os politiqueiros, os depravados, os ociosos, sejam eles centuriões, patrícios, plebeus ou até mesmo o imperador, propondo-lhes o espelho da "verdadeira liberdade" humana (entendida como a sujeição das paixões), das limitações da vida, da abnegação.

O leitor ao qual Pérsio se dirige - asseveram Gianotti e Pennacini - deve ser não apenas um iniciado no estoicismo, mas também alguém capaz de decifrar as múltiplas ambiguidades do poeta. Seu público são os membros da aristocracia de sangue e de dinheiro que, desde Augusto, fora alijada do poder político e encontrou no estoicismo uma forma de oposição. Sua ambiguidade decorre do emprego sistemático de figuras retóricas e procedimentos que objetivam a desmistificação das falsas aparências seguida da recuperação da "veracidade". "Vero", "autêntico", "real", contudo, são entendidos aqui em sentido ético, distinguindo o humano do "monstruoso" - isto é, dos simulacros da virtude e da beleza. 
Assim, a primeira operação é "tirar a pele" (detrahere pellem, conforme escreve Horácio sobre Lucílio) que reveste o vício e a ambição, desvendando-as perante o leitor. Este, para chegar a tal reconhecimento, é induzido a identificar os artifícios retóricos, a decifrar metáforas e metonímias, a apreciar a dubiedade produzida por construções insólitas. Desse modo o satirista põe em ação o "estranhamento", considerado por Aristóteles como a mais significativa característica da poesia: ${ }^{8}$ com a frustração da expectativa, provocada pela inserção de elementos heterogêneos, propõe ao leitor uma renovada percepção das palavras e dos objetos, com o que o poeta pretende alcançar a verum - agora despida da pele que a recobria, revelando-se em sua autêntica abjeção (GIANOTTI \& PENNACINI, v. 2, p. 56-7).

Semelhante propósito - prosseguem Gianotti e Pennacini - se traduz em técnicas e elementos estruturais das sátiras de Pérsio, cujos temas são descritos de ângulos diversos, de modo a requisitar do leitor o confronto entre o usual e o inesperado, encaminhando-o à desmistificação das aparências. Daí o recurso, buscado principalmente em Lucílio, de mesclar os estilos e os estratos linguísticos, produzindo descrições estranhas, a surpresa e o suspense. A própria escolha do vocabulário obedece a esses critérios. Na "Sátira I", por exemplo, na qual o autor dialoga com um partidário anônimo da poesia helenizante em moda nos tempos de Nero, Pérsio, empregando técnica proveniente da tradição da diatribe cínico-estóica, se serve de campos lexicais que designam a realidade física, os quais parecem dotados de privilegiada eficácia desmistificadora ao remeterem a uma esfera de significados por si mesma abominável e abjeta. Assim, a corrupção do gosto do público atento à pompa vã dos recitais acentua-se mediante descrições estranhas nas quais a função de recuperar o autêntico - isto é, a própria

\footnotetext{
8 "[...] não é ofício do poeta narrar o que aconteceu; é sim, o de representar o que poderia acontecer, quer dizer: o que é possível segundo a verossimilhança e a necessidade. Com efeito, não diferem o historiador e o poeta por escreverem em verso ou prosa [...] - diferem, sim, em que diz um as coisas que sucederam, e outro as que poderiam suceder. Por isso a poesia é algo mais filosófico e mais sério do que a história [...]". ARISTÓTELES, 1993, p. 54-5.
}

corrupção — vem envolvida pelo vocabulário relativo ao corpo e ao sexo, encenando situações e personagens abjetas (GIANOTTI \& PENNACINI, v. 2, p. 57-8).

Entre Pérsio e Juvenal, a sátira tal como foi instituída por Lucílio e sistematizada por Horácio legou poucos resquícios. Há apenas notícia e fragmentos de textos de outros poetas satíricos em Roma, nesse período: P. Manílio Vopisco, um certo Sílio, Júlio Rufo e Turno - além da atribuição (incorreta, ao que tudo indica) de versos satíricos a uma poetisa chamada Sulpícia (BEVILACQUA, p. 813). Por outro lado, há uma proliferação de epigramas satíricos, nos quais o ataque a personalidades vivas - então interditado - é feito veladamente (GIANOTTI \& PENNACINI, v. 2, p. 83), e da sátira menipeia - que ocupa, como querem Gianotti e Pennacini, o primeiro plano no surgimento e desenvolvimento da narrativa latina (GIANOTTI \& PENNACINI, v. 2, p. 58). Da sátira menipeia, além dos seiscentos fragmentos das Saturae menippeae de Varrão, ficaram a Divi Claudii apokolokyntosis de Sêneca, trechos de três livros do Satyricon - de controversa atribuição a um certo Petronius Arbiter (que alguns estudiosos identificam com Caio Petrônio, figura proeminente da corte de Nero) - e as Metamorfoses de Apuleio.

O surgimento e o êxito da sátira em versos hexâmetros, com Lucílio, possibilitou também a aparição, entre os anos 80 e 45 a. C., da satura compreendida como mescla de prosa e várias métricas. É o caso das já referidas Saturae menippeae de Varrão, que buscou em Menipo de Gadara - filósofo cínico do século III a. C. que predicava o abandono da civilização grega e a vida conforme a natureza - o modo da composição em verso e prosa. Mas Varrão acrescentou a esse elemento uma polimetria que pode remontar a Ênio e a poetas contemporâneos. Contudo, enquanto o cínico Menipo acusava a sociedade e a civilização de terem corrompido a pureza natural do ser humano e conclamava todos ao desprezo dos desejos e das convenções, Varrão ataca o mundo coevo porque 
degradado em relação aos virtuosos tempos primitivos de Roma.

Cerca de um século mais tarde, Sêneca compôs a Apokolokyntosis, igualmente misto de prosa e verso, marcada por paródias e personagens caricaturais, em que o imperador Cláudio, depois de morto e após uma série de peripécias, é lançado aos infernos, onde receberá ordens de libertos exatamente a crítica que Ihe fazia a oligarquia, opondo-se ao poder imperial. Em diversas passagens a obra parodia o estilo sublimis da tragédia, enquanto aplica, sobretudo nas partes em prosa, o estilo humilis, recorrendo ao coloquial (GIANOTTI \& PENNACINI, v. 2, p. 54-5).

As Metamorfoses (ou $O$ asno de ouro) de Apuleio (século II d. C.), que narra a transformação do curioso Lúcio em asno e sua longa peregrinação - tal como Ulisses - até merecer o final feliz, também parodia a épica. Trata-se de uma mescla de pequenos contos, casos trágicos, histórias de feitiçaria e mitos filosóficos cujo argumento aparece em texto anterior, hoje desaparecido e atribuído a um certo Lúcio de Patras. A narrativa em episódios curtos constitui um relato iniciático que, sob a máscara cômica, louva a deusa Ísis, salvadora da personagem Lúcio, a quem este deve o retorno à forma humana após penosa peregrinação.

A poesia epigramática, de variada métrica, encontra suas primeiras manifestações latinas em Catulo, entre o fim do século II e o início do século I a. C.. Caracterizado pela brevidade e pela concisão uma vez que inicialmente se destinava a figurar em monumentos, em especial tumbas e pedestais -, o epigrama foi praticado por vários poetas na Grécia, entre os quais Arquíloco e Calímaco de Cirene. Na variada obra de Catulo há pelo menos quarenta e oito pequenas peças - ou cento e dezesseis, como querem René Martin e Jacques Gaillard - que se enquadram nessas características, ocupando-se de temas como os amores, os desafetos e as amizades da persona poética com recurso a um vocabulário bastante familiar ou até mesmo trivial e frequentemente grosseiro. Nos epigramas catulianos encontram-se, por exemplo, a pequena prostituta, o pederasta, o rival no amor - que é tratado com particular violência - compondo, com variado grau de sarcasmo e obscenidade, considerável galeria de caricaturas. Porém, as invectivas de Catulo não poupam o próprio César, a cujos partidários atribui diversas "taras", sem omitir a efeminação e a pederastia. Assim, Mamurra, lugar-tenente de César, é designado pelo cognome obsceno "Mentula" (o órgão sexual masculino, em latim), enquanto o mesmo César é chamado de "Rômulo invertido" e vituperado como impudico e voraz, um jogador que se entende melhor com seu insuportável auxiliar. Idêntico tipo de ataque epigramático foi composto por um contemporâneo de Catulo, Licínio Calvo, em cujos fragmentos se localizam menções a um suposto amor entre César e Nicomedes (CÈBE, p. 188-9). Tanto Catulo quanto Licínio pertencem a um grupo de "novos poetas" que, entre os anos 80 e 50 a. C., definem a poesia como a arte da perfeição formal o que os leva a optar pelos gêneros breves, entre os quais o epigrama, em contraposição à poesia épica. Mas foi em Marco Valério Marcial, nascido por volta do ano 40 e morto em 104 d. C., que o gênero teve seu mais reconhecido praticante em Roma. Seus epigramas estão reunidos em quinze livros, dos quais doze são estritamente epigramáticos, no sentido que então essa forma poética assume: agressivos, contundentes, irônicos, desmistificadores. Nele, bem ao sabor da sátira horaciana, desfilam expectativas e desilusões, a idealização dos valores simples e elementares da vida rural contraposta à vida urbana - constituída, por sua vez, por uma galeria de caricaturas, esquálidas figuras de poetrastos e falsos filósofos, charlatães, homens pouco virtuosos, avaros, embusteiros (GIANOTTI \& PENNACINI, v. 3, p. 64-6). Trata-se de uma forma poética geralmente cultivada no otium, entre amigos ou pessoas próximas, dificilmente apresentando um caráter impessoal ou atemporal, conforme resumem Martin e Gaillard ( $p$. 405).

Contudo, a poesia satírica produzida segundo a tradição instituída por Lucílio e codificada por Horácio é retomada principalmente por Décimo Júnio Juvenal, que nasceu entre 55 e 60 e faleceu 
provavelmente após ao ano 127 d. C., desenvolvendo sua atividade poética sob Nerva, Trajano e Adriano. Suas dezesseis sátiras, repartidas em cinco livros, foram compostas em versos hexâmetros, dos quais ressuma - conforme sustentam Gianotti e Pennacini - o retorno a um antigo estado de coisas, à Roma antiquíssima, das origens, ou aos ideais da libertas republicana: "difficile est saturam non scribere" (JUVENAL, p. 46), lamenta a persona satírica, lançando um olhar sempre pessimista sobre o presente (tanto que seus poemas se dirigem aos mortos, ainda que recentes). Logo na primeira sátira, indignado com o espetáculo de corrupção da vida contemporânea, Juvenal decide endereçar suas farpas à geração passada para se proteger do ódio e da vingança coevos que ameaçariam os poetas satíricos. O artifício lhe permite a representação caricata de personagens que propiciam a explicitação de juízos éticos muito caros à nobreza agora afastada do poder — daí a nostalgia da era republicana, isto é, do governo colegiado da oligarquia. A instauração da monarquia, o enriquecimento e o crescente poder dos libertos - que chegam a ministros, sob Cláudio -, o desaparecimento ou a decadência das grandes famílias nobres - que antes protegiam os artistas as alterações no direito familiar, concedendo à mulher uma condição jurídica bastante próxima à masculina, são mudanças que indignam o satirista, que vê nesse "nivelamento" político a própria desordem em que a sociedade romana se encontra (GIANOTTI \& PENNACINI, v. 3, p. 68-9). Semelhante postura de restauração e conservação da antiga ordem social prosseguem Gianotti e Pennacini - se traduz, no plano formal, em alguns procedimentos que, mantendo as características tradicionais da sátira - a mescla de estilos, por exemplo —, em Juvenal adquirem outra função: não se trata mais de desmistificar objetos e palavras recuperando a verdadeira abjeção mediante o encontro do estilo sublimis com o humilis. Na realidade, a corrupção, a abjeção, a torpeza e os vícios humanos são de tal proporção que apenas o estilo sublimis da tragédia e da épica podem representar sua incomensurável estatura e horror. As dimensões da culpa exigem não o estilo baixo e a língua vulgar, mas o estilo alto e a língua áulica para descobrir, sob a pele da normalidade, a vileza, a baixeza, a desonestidade (GIANOTTI \& PENNACINI, v. 3, p. 68). Desse modo, os alvos da sátira juvenaliana são os hipócritas que encobrem sua torpeza sob uma enganosa aparência de virtuosidade, comportamento que tem na homossexualidade masculina a vítima preferencial dos doestos ("Sátira II"); a Roma que o amigo Umbrício abandona porque "Quando artibus, inquit, honestis / nullus in Vrbe locus, nulla emolumenta laborum" ("Sátira III"); a corte imperial, ironizada por meio de uma reunião do conselho de Domiciano para deliberar, com penosa gravidade, sobre a maneira de cozinhar um gigantesco peixe oferecido ao imperador ("Sátira IV"); a humilhante condição do cliente ("Sátira V"); a mísera situação dos letrados agravada pela decadência geral dos estudos, pela mesquinhez dos novos-ricos e pelo fim do mecenato - responsável pela grande poesia dos tempos de Augusto ("Sátira VII"); a vã nobreza dos títulos e ancestrais ilustres ("Stemmata quid faciunt, quid prodest, Pontice, longo / saguine censeri, pictos ostendere vultus / maiorum [...]?") em contraposição ao autêntico enobrecimento proporcionado pelo talento e pela pureza dos sentimentos ("Sátira VIII"); o homossexual mal recompensado por seus vis serviços ("Sátira IX"); a cegueira dos desejos humanos ("Sátira X"); a gula e a ostentação dos banquetes dos abastados ("Sátira XI"); os caçadores de heranças ("Sátira XII”); os ladrões e os trapaceiros ("Sátira XIII"); o mau exemplo dos pais deseducando os próprios filhos ("Sátira XIV"); o fanatismo e a superstição, a propósito de um episódio de canibalismo no Egito ("Sátira XV"). A "Sátira XVI", por fim, da qual restaram apenas sessenta versos, exalta os benefícios da vida militar (GIANOTTI \& PENNACINI, v. 3, p. 67).

A sátira juvenaliana está longe de ser o fim do percurso iniciado com a obra de Lucílio. Apesar da escassez de documentos, é possível constatar, dentro e fora da Igreja — mas sobretudo dentro —, ao lado da tradição carnavalesca e da paródia letrada à poesia greco-latina, a continuidade desta última após o desaparecimento do Império Romano no Ocidente. 
Horácio, por exemplo, é frequentemente citado por são Jerônimo, já no século IV. Um dos mais próximos colaboradores de Carlos Magno - Alcuino Albinus Flaccus, um dos expoentes do "renascimento carolíngio" - agregou ao próprio sobrenome uma explícita referência horaciana. E o mais antigo manuscrito da obra de Horácio data do século IX, copiado na abadia de Fleury-sur-Loire, na França. A partir do século XI proliferam as cópias e surge o costume de "cantar" odes e poemas líricos de Horácio em festas cortesãs. Os demais poetas satíricos clássicos, apesar das referências mais dispersas, continuaram a ser lidos pela restrita elite letrada medieval, principalmente em função do ensino do latim e da retórica. Comentários a Horácio, Pérsio e Juvenal - empenhados em cristianizá-los, como é de supor -, localizados no mosteiro alemão de Saint Gall (1066) e em Colônia (século XI ou XII), atestam a sobrevivência desses autores ao longo de toda a Idade Média - inclusive entre homens e mulheres cultos das inúmeras cortes europeias. As comédias gregas - conhecidas sobretudo em traduções latinas - e romanas foram igualmente retomadas nas escolas e, desde o século $\mathrm{XI}$, reaparecem no teatro profano (escrito em latim) a partir da apropriação de Plauto e Menandro, entre outros autores. Uma obra de autor desconhecido, possivelmente do século XII, difundiu-se bastante pela Europa encenando uma história erótica que imitava Ovídio e Plauto: trata-se da comédia Pamphilus, provável item da bibliografia escolar de então, cuja versão em espanhol Pamphilo - , realizada por Juan de Flores (que viveu entre os séculos $\mathrm{XV}$ e XVI), é uma das poucas evidências das relações com esse teatro cômico em latim na Península Ibérica, sendo imitada por Fernando de Rojas em sua Celestina - que, por sua vez, constituiu uma das fontes do teatro de Gil Vicente. A popularidade de Pamphilus, aliás, pode estar na origem da palavra "panfleto" (LOPES, p. 60).

A produção ibérica medieval de uma poesia profana em latim com semelhante teor ainda não foi confirmada, embora haja uma coleção hispânica de textos goliárdicos - os Carmina rivipullensia (Canções do mosteiro de Ripoll), compilação do século XII. Entre as práticas poéticas em vernáculo, porém, as cantigas de escárnio e maldizer galegoportuguesas são dos mais remotos indícios de uma poesia local de viés satírico ainda na Idade Média, num fenômeno que se manifestava em outros pontos da Europa. Contudo, as relações entre a sátira dos cancioneiros medievais galego-portugueses e as tradições "popular", latina e árabe não são imediatas e permanecem até como um problema de certo modo insolúvel - sustenta Graça Lopes (p. 67). Assim, seria equivocada qualquer linha evolutiva que traçasse a ascendência genealógica da sátira medieval galego-portuguesa filiando-a imediatamente ao gênero clássico que lhe corresponderia. A poesia satírica

[...] toma a sua forma medieval própria a partir de um "processo de criação e modificação" do antigo, antigo que não pode ser resumido, na Idade Média, como fará mais tarde a literatura renascentista, ao antigo "clássico", tal como se define, por exemplo, na sátira horaciana. (LOPES, p. 69)

É exatamente a apropriação desta última, já no Quinhentos português, que interessa ao presente artigo, embora em meados do século XV haja evidências da retomada peninsular da concepção didático-moral da sátira segundo o modelo latino conforme se observa na "Satira de infelice e felice vida", do condestável d. Pedro de Portugal (14291463), filho do duque de Coimbra.

No teatro de Gil Vicente a tradição moralizante da sátira (mediante a constituição de personagens e situações cômicas, burlescas e grotescas) pode ser detectada com bastante nitidez, naquele início do Quinhentos português. Em peças como o Auto de Inês Pereira, por exemplo, a ridicularização de determinado tipo - o vilão - repõe, à maneira satírica, a ordem que a desordem inverteu (BERNARDES, p. 226).

Semelhante postura é adotada em trovas do Cancioneiro geral de Garcia de Resende, impresso em 1516, mas que recolhe composições datáveis desde 1449, abrigando "várias sátiras ou reflexões desabusadas sobre as alterações sociais, a dissolução dos costumes e a ambição desenfreada que deles resultaram" (CRABBÉ-ROCHA, p. 14). O 
mesmo se pode dizer - quanto aos paradigmas da obra de Francisco de Sá de Miranda (1481-1558), que viveu na Itália de 1521 a 1526 (passando pela Espanha neste último ano, ao retornar), de onde trouxe o dolce still nuovo, introduzindo em Portugal novas estruturas métricas, como o decassílabo, e outras formas estróficas, como o terceto, a oitava e o soneto - além de inaugurar no reino luso a prática de subgêneros líricos como o canto, a canção, a elegia, a écloga e a carta. Tendo provavelmente convivido com Bembo, Sannazzaro e Ariosto na península itálica, conheceu os castelhanos Juan Boscan e Garcilaso de la Veja (BENEDITO, p. 7-28). Autor de duas comédias, revelou-se plenamente atualizado não só com os modelos de composição, mas também com o aparato ético-filosófico clássico - devidamente cristianizado - recuperado na Europa ocidental quinhentista.

A aplicação de técnicas de efeito cômico com o objetivo de submeter ao riso leve - isto é, ao ridículo - determinados vícios ou comportamentos inofensivos, pode ser constatada na produção satírica dos estudantes da Universidade de Coimbra que, a partir de 1746, passam a imprimir poemas de codificação muito peculiar ironizando a vida do universitário coimbrão, apropriando-se da murmuração local que o constituía como um tipo boêmio. Trata-se do Palito metrico lavrado no lorvã̃ da pachorra com a ferramenta da cachimonia, embrulhado no titulo de Calouriada, e offerecido aos refaloes do Parnaso no esquipatico pires de hum Poema mestiço por Antonio Duarte Ferram, assinado provavelmente com pseudônimo, que pode decorrer de prática corrente anterior. O poema, que narra as aventuras do novato João Fernandes, parodia convenções da épica e mescla elementos picarescos a uma forma em si mesma cômica: o autor "alatinou o seu vocabulário mantendo-Ihe o plebeísmo da locução portuguesa corrente, e construíu o discurso segundo a sintaxe latina" (MADAHIL, p. IX). Às sucessivas edições do Palito metrico se agregaram outras composições similares, que em 1765 resultaram na publicação da Macarronea latinoportugueza, reeditada e acrescida — inclusive com poemas apenas em português - pelo menos sete vezes até 1913.

Ronald Polito localizou, na Biblioteca Geral da Universidade de Coimbra, obras compostas em Minas Gerais satirizando o governo de d. Lourenço de Almeida (1721-1732). Uma delas — "Obra cômica, ou satírica descrição dos [canotados] indiscretos de dom Lourenço de Almeida, governador destas Minas, que só agora acabado o seu governo, ou desgoverno, podem justamente respirar das opressões com que há largos onze anos se acham subjugados: sendo esta católica repreensão dada pelos versículos do Psalm. 51, que parece foi feito ad intentum, com inteligência dos versos que se the acrescentam: porque seguindo o mesmo profeta rei, se devem as maldades públicas publicamente corrigir iniquor ad io habus" - se serve do recurso de intercalar frases em português com trechos inteiros do "Salmo 51" em latim, sem, contudo, empregar a mescla burlesca do Palito métrico. Além dessa peça, Polito encontrou o "Segundo ofício que mandou fazer Pedro da Costa Guimarães pela alma de d. Lourenço, reformado pelo mesmo autor" - que emula papéis públicos, detalhando o "segundo ofício" que Guimarães manda celebrar pela alma do governador, "porque os sacerdotes, no primeiro, se mostraram tíbios, talvez que como mais legítimos filhos da Igreja, escandalizados do dinheiro que com a sua capa a esta se usurpou, porque nem contra a sua ambiciosa cobiça valeu a imunidade dos templos". O "Romance satírico em que se descrevem as ações de um tão ilustre herói como é dom Lourenço de Almeida, escritas em diálogo, em que fala o secretário João da Costa Carneiro, o mesmo dom Lourenço, e o padre Felipe de Almeida, reduzindo-o a que faça testemunho, interpretando metaforicamente a morte pela entrega que faz do governo destas Minas, em que só é empenho do autor, dar algum divertimento aos moradores delas, que há tantos anos gemem debaixo do cativeiro deste inumano Faraó, por cujo motivo o tem tomado por seu mecenas", assinado por certo "Bizorreira", simula, em forma de diálogo, testamento do governador ditado ao seu secretário. Também parodiando convenções do discurso 
burocrático - mais precisamente, as das cartas de alforria —, há a "Escritura condicional de liberdade que dá dom Lourenço de Almeida aos moradores das Minas”. A matéria, as tópicas e o procedimento discursivo dessas produções satíricas merecem um estudo à parte. Para o presente artigo, o que importa reter é a ocorrência de práticas discursivas letradas de teor satírico em Minas Gerais já na década de 1730 - quando a historiografia em geral e a da literatura em particular costumam mencionar apenas as Cartas chilenas, ao tratar de sátira setecentista na capitania - e os indícios de que a prática era corrente. Aliás, textos satíricos parodiando convenções de documentos cartorários têm longa tradição em Portugal e parece ter sido vigorosa ainda no século XVIII. Já no século XV, no Cancioneiro geral de Garcia de Resende, há, por exemplo, o "testamento" do "macho ruço" de Luís Freire personagem retratado pelo próprio muar agonizante como um dono avaro, sempre muito mesquinho na ração (CANCIONEIRO GERAL..., v. 3, p. 287-90). Durante o carnaval lisboeta de 1740 circularam, entre os poemas satíricos que glosavam o recente decreto punindo 0 abuso de tratamentos de distinção, quarenta e cinco décimas intituladas "O testamento da Senhoria", atribuídas - com bastante cautela por Tiago dos Reis Miranda a Tomás Pinto Brandão (1664-1743). Com versões diferentes, encontradas em bibliotecas diversas por Miranda, o poema delata nomes e alcunhas de proeminentes "casquilhos" do reinado de $\mathrm{d}$. João $\mathrm{V}$ que encenam, na sátira, "um compungido cortejo pela memória da Senhoria" ou atuam como "testemunhas da validade do instrumento que ela lavrara, em debochada reprodução das formas prescritas pelos costumes e pelas leis positivas do reino" (MIRANDA, p. 21).

Generalizada entre os letrados como veículo da ética cortesã e da política católica, a sátira adentra o século XVIII português também como arma na intensa batalha contra os versos "cultos" que então se travará, como se pode depreender do poema "Pombasília de Apolo", de autor anônimo certamente setecentista, recolhido no Postilhão de Apolo organizado por Joseph Maregelo de Osan (anagrama de d. José Ângelo de Morais) e publicado, em dois volumes, já sob o reinado de d. José I (a quem é dedicado), entre 1761 e 1762. Ataques dessa natureza a versos "Tão cegos, tão escuros, tão ocultos" não se reduzem a uma questão meramente estilística, mas integram o intenso debate que, durante a segunda metade do século XVIII luso com desdobramentos ainda na primeira metade do seguinte, como se vê pela monografia de Macedo que abriu o presente texto - , marcará toda a cultura letrada portuguesa, propondo a superação da filosofia escolástica - confundida com o ensino ministrado pelos jesuítas - e nova maneira de fazer poesia, identificada com a política pombalina. Assim, a clareza, a ordem e a elegância agora passam a ser atributos que caracterizam o "saber pensar":

Este é, enfim, o estilo racional preconizado por toda a mentalidade ilustrada em Portugal. [...] A Arte Poética de Francisco José Freire, cuja segunda edição também foi patrocinada por Pombal (1759), é particularmente preocupada com esses princípios (clareza, ordem, elegância), nos quais repousam o ideal de perfeição e beleza em poesia na época. (TEIXEIRA, p. 45-6)

Inseridos, pois, na milenar tradição retóricopoética que aqui se procurou resumir, os poemas herói-cômicos em língua portuguesa escritos na segunda metade do século XVIII e primeiros anos do XIX não podem prosseguir sendo apropriados pela historiografia como "retrato" ou "ilustração" das sociedades que os produziram. Formulação óbvia, mas basta percorrer monografias, dissertações e teses já do século XXI para constatar a persistência do "sociologismo" na invenção desses poemas como documentos históricos. Documentos, sim, mas como discursos irredutíveis a determinismos sociológicos ou de qualquer natureza. Históricos, sim, mas como ruínas que suportam, quando muito - como diria Flaubert -, a tristeza necessária para reconstituir Cartago.

\section{Referências}

ACHCAR, Francisco. Lírica e lugar-comum; alguns temas de Horácio e sua presença em português. São Paulo, Edusp, 1994. 
ARISTÓTELES. "Arte retórica". In: Arte retórica e Arte poética. Trad. Antônio Pinto de Carvalho. Rio de Janeiro, Tecnoprint, 1969. p. 27-269.

ARISTÓTELES. Poética. Trad. Eudoro de Sousa. 2. ed. São Paulo, Ars Poética, 1993.

BENEDITO, Silvério Augusto. "Introdução". In: MIRANDA, Francisco de Sá de. Poesia e teatro. s/l, Ulisséia, [1988]. p. 7-45.

BERNARDES, José Augusto Cardoso. Sátira e lirismo; modelos de síntese no teatro de Gil Vicente. Coimbra, Universidade de Coimbra, 1996.

BEVILACQUA, Michele. Sulla storia della satira romana. Roma, Elia, s/d.

CANCIONEIRO geral de Garcia de Resende. Lisboa, Imprensa Nacional, 1990. v. 1 e 3.

CÈBE, Jean-Pierre. La caricature et la parodie dans le monde romain antique; des origines a Juvénal. Paris, Bocard, 1966.

CRABBÉ-ROCHA, André. Garcia de Resende e o Cancioneiro geral. 2. ed. Lisboa, Instituto de Cultura e Língua Portuguesa, 1987.

CURTIUS, Ernst Robert. Literatura européia e Idade Média latina. Trad. Paulo Rónai e Teodoro Cabral. São Paulo, Edusp, 1996.

FLACO, Aulo Pérsio \& JUVENAL, Décimo Júnio. Sátiras. Trad. Miguel Dolç. Madri, Gredos, 1991.

GIANOTTI, Gian Franco \& PENNACINI, Adriano. Società e comunicazione litteraria di Roma antica. 2. ed. Turim, Loescher, 1986. 3. v.

HANSEN, João Adolfo. "Engenho" [notas para a pósgraduação]. São Paulo, mimeo., 1997.

HANSEN, João Adolfo. A sátira e o engenho; Gregório de Matos e a Bahia do século XVII. São Paulo, Companhia das Letras, 1989.

JUVENAL, Décimo Júnio. Satire. Trad. Ettore Barelli. 4. ed. Milão, Rizzoli, 1989.

LAUSBERG, Heinrich. Elementos de retórica literária. Trad. R. M. Rosado Fernandes. 4. ed. Lisboa, Calouste Gulbenkian, 1993.
LOPES, Graça Videira. A sátira nos cancioneiros medievais galego-portugueses. Lisboa, Estampa, 1994.

MACEDO, José Agostinho de. Os jesuitas, e as letras ou a pergunta respondida. Lisboa, Impressão Régia, 1830.

MADAHIL, A. G. da Rocha. [Introdução]. In: PALITO métrico e correlativa macarrónea latinoportuguesa. Coimbra, Coimbra Editora, 1942.

MARTIN, René \& GAILLARD, Jacques. Les genres littéraires à Rome. Paris, Nathan, 1990.

MIRANDA, Tiago C. P. dos Reis. "O testamento da Senhoria': poema satírico atribuído a Tomás Pinto Brandão (1740) ". Festa: cultura e sociabilidade na América portuguesa [caderno de resumos]. São Paulo, FFLCH-USP, 1999. p. 21.

PLEBE, Armando. Breve história da retórica antiga. Trad. Gilda Naécia Maciel de Barros. São Paulo, EPU/Edusp, 1978.

POLITO, Ronald. A persistência das idéias e das formas; um estudo sobre a obra de Tomás Antônio Gonzaga. (Dissertação de mestrado apresentada ao Departamento de História da UFF) Niterói, 1990.

POLITO, Ronald \& LIMA, José Arnaldo Coelho de Aguiar. As sátiras inéditas contra dom Lourenço de Almeida (1721-1732) (Projeto de pesquisa apresentado à Fundação de Amparo à Pesquisa do Estado de Minas Gerais) Mariana, 2000.

TEIXEIRA, Ivan. Mecenato pombalino e poesia neoclássica; Basílio da Gama e poesia neoclássica. São Paulo, Edusp, 1999.

\section{COMO CITAR ESSE ARTIGO}

FURTADO, Joaci Pereira. Satura, saturae: itinerários do misto (preceptivas do poema herói-cômico no mundo luso-colonial). Signo, Santa Cruz do Sul, v. 42, n. 73, jan. 2017. ISSN 1982-2014. Disponível em: $<$ https://online.unisc.br/seer/index.php/signo/article/view/7852>. Acesso em: http://dx.doi.org/10.17058/signo.v42i73.7852. 